Prepared for the U.S. Department of Energy

under Contract DE-AC05-76RL01830

\title{
Energy Use Savings for a Typical New Residential Dwelling Unit Based on the 2009 and 2012 IECC as Compared to the 2006 IECC
}

\section{Letter Report}

\section{RG Lucas}

VV Mendon

\author{
S Goel
}

April 2013

Pacific Northwest

NATIONAL LABORATORY

Proudly Operated by Battelle Since 1965 


\title{
DISCLAIMER
}

This report was prepared as an account of work sponsored by an agency of the United States Government. Neither the United States Government nor any agency thereof, nor Battelle Memorial Institute, nor any of their employees, makes any warranty, express or implied, or assumes any legal liability or responsibility for the accuracy, completeness, or usefulness of any information, apparatus, product, or process disclosed, or represents that its use would not infringe privately owned rights. Reference herein to any specific commercial product, process, or service by trade name, trademark, manufacturer, or otherwise does not necessarily constitute or imply its endorsement, recommendation, or favoring by the United States Government or any agency thereof, or Battelle Memorial Institute. The views and opinions of authors expressed herein do not necessarily state or reflect those of the United States Government or any agency thereof.

\author{
PACIFIC NORTHWEST NATIONAL LABORATORY \\ operated by \\ BATTELLE \\ for the \\ UNITED STATES DEPARTMENT OF ENERGY \\ under Contract DE-AC05-76RL01830
}

Printed in the United States of America
Available to DOE and DOE contractors from the Office of Scientific and Technical Information,
P.O. Box 62, Oak Ridge, TN 37831-0062;
ph: (865) 576-8401
fax: $(865) 576-5728$
email: reports@adonis.osti.gov

\footnotetext{
Available to the public from the National Technical Information Service, U.S. Department of Commerce, 5285 Port Royal Rd., Springfield, VA 22161 ph: (800) 553-6847 fax: $(703) 605-6900$ email: orders@ntis.fedworld.gov online ordering: http://www.ntis.gov/ordering.htm
}

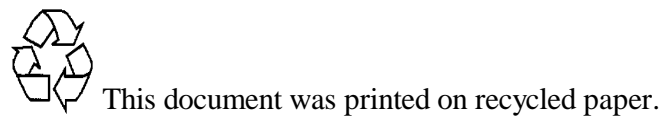




\section{Energy Use Savings for a Typical New Residential Dwelling Unit Based on the 2009 and 2012 IECC as Compared to the 2006 IECC}

\section{Letter Report}

RG Lucas

VV Mendon

S Goel

April 2013

Prepared for

the U.S. Department of Energy

under Contract DE-AC05-76RL01830

Pacific Northwest National Laboratory

Richland, Washington 99352 



\section{Contents}

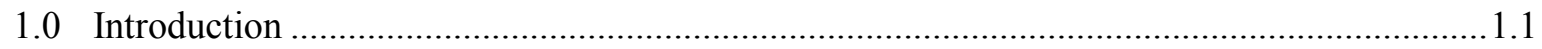

2.0 Overview of Energy Simulation Analysis Methodology.....................................................2.1

2.1 Energy Savings for an Average Dwelling Unit ........................................................... 2.1

2.2 Total Annual Energy Savings for all Residential Construction ....................................2.5

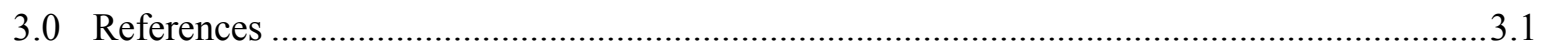





\subsection{Introduction}

The 2009 and 2012 International Energy Conservation Codes (IECC) require a substantial improvement in energy efficiency compared to the 2006 IECC. This report averages the energy use savings for a typical new residential dwelling unit based on the 2009 and 2012 IECC compared to the 2006 IECC. Results are reported by the eight climate zones in the IECC and for the national average. 



\subsection{Overview of Energy Simulation Analysis Methodology ${ }^{1}$}

Energy use is calculated using EnergyPlus ${ }^{\mathrm{TM}}$ software, Version 5.0. Two buildings are simulated: a 2,400 $\mathrm{ft}^{2}$ single-family home and an apartment building (a three-story multifamily prototype having six dwelling units per floor) with $1,200 \mathrm{ft}^{2}$ dwelling units. These results are combined into a composite average dwelling unit based on 2010 Census building permit data. Single-family home construction is more common than low-rise multifamily construction; the results are weighted accordingly to reflect this. Census data also is used to determine climate zone and national averages weighting for construction activity.

Four heating systems are considered: natural gas furnaces, oil furnaces, electric heat pumps, and electric resistance furnaces. The shares of heating system types were obtained from the U.S. Department of Energy Residential Energy Consumption Survey (2009). Domestic water heating systems are assumed to use the same fuel as the space heating system.

All energy use shown here is in source, or primary energy. Electricity is assumed to have a 3.16 siteto-source conversion factor. ${ }^{2}$ Natural gas is assumed to have a 1.10 site-to-source conversion factor. ${ }^{2}$ These are both used as simple multipliers to scale site energy usage, in British thermal units (Btu), to source energy.

\subsection{Energy Savings for an Average Dwelling Unit}

Tables 1 through 5 present the annual energy use in million Btu per dwelling unit. Figures 1 through 5 present the same information graphically. Total energy use is shown in Table 1 and Figure 1. Energy end-uses included here are those regulated by the IECC: space heating, space cooling (air conditioning), domestic water heating, and lighting.

Table 1. Annual Energy Use (Source Energy, Million Btu) for a Dwelling Unit for all IECC Regulated End-Uses (Heating, Cooling, Water Heating, and Lighting)

\begin{tabular}{|l|c|c|c|}
\hline & 2006 IECC & 2009 IECC & 2012 IECC \\
\hline Zone 1 & 122 & 110 & 91 \\
\hline Zone 2 & 141 & 122 & 104 \\
\hline Zone 3 & 134 & 118 & 88 \\
\hline Zone 4 & 154 & 139 & 103 \\
\hline Zone 5 & 171 & 154 & 114 \\
\hline Zone 6 & 199 & 179 & 126 \\
\hline Zone 7 & 244 & 220 & 151 \\
\hline Zone 8 & 399 & 358 & 244 \\
\hline National Average & 153 & 137 & 104 \\
\hline
\end{tabular}

\footnotetext{
${ }^{1}$ For more information on how these estimates were developed, visit the DOE Building Energy Codes website: www.energycodes.gov/development/residential.

${ }^{2}$ These factors are from Section R405 of the 2012 IECC.
} 
Table 2. Annual Energy Use (Source Energy, Million Btu) for a Dwelling Unit for Heating

\begin{tabular}{|l|c|c|c|}
\hline & 2006 IECC & 2009 IECC & 2012 IECC \\
\hline Zone 1 & 2 & 2 & 1 \\
\hline Zone 2 & 27 & 24 & 16 \\
\hline Zone 3 & 47 & 41 & 21 \\
\hline Zone 4 & 75 & 64 & 37 \\
\hline Zone 5 & 101 & 89 & 54 \\
\hline Zone 6 & 133 & 117 & 69 \\
\hline Zone 7 & 180 & 159 & 96 \\
\hline Zone 8 & 328 & 291 & 183 \\
\hline National Average & 68 & 59 & 34 \\
\hline
\end{tabular}

Table 3. Annual Energy Use (Source Energy, Million Btu) for a Dwelling Unit for Cooling

\begin{tabular}{|l|c|c|c|}
\hline & 2006 IECC & 2009 IECC & 2012 IECC \\
\hline Zone 1 & 83 & 74 & 60 \\
\hline Zone 2 & 71 & 58 & 51 \\
\hline Zone 3 & 41 & 34 & 29 \\
\hline Zone 4 & 29 & 28 & 25 \\
\hline Zone 5 & 23 & 22 & 21 \\
\hline Zone 6 & 18 & 17 & 16 \\
\hline Zone 7 & 11 & 11 & 11 \\
\hline Zone 8 & 7 & 7 & 7 \\
\hline National Average & 39 & 34 & 30 \\
\hline
\end{tabular}

Table 4. Annual Energy Use (Source Energy, Million Btu) for a Dwelling Unit for Domestic Water Heating

\begin{tabular}{|l|c|c|c|}
\hline & 2006 IECC & 2009 IECC & 2012 IECC \\
\hline Zone 1 & 20 & 20 & 18 \\
\hline Zone 2 & 23 & 23 & 21 \\
\hline Zone 3 & 27 & 27 & 24 \\
\hline Zone 4 & 30 & 30 & 27 \\
\hline Zone 5 & 28 & 28 & 25 \\
\hline Zone 6 & 30 & 30 & 27 \\
\hline Zone 7 & 34 & 34 & 31 \\
\hline Zone 8 & 42 & 42 & 38 \\
\hline National Average & 27 & 27 & 25 \\
\hline
\end{tabular}


Table 5. Annual Energy Use (Source Energy, Million Btu) for a Dwelling Unit for Lighting

\begin{tabular}{|l|c|c|c|}
\hline & 2006 IECC & 2009 IECC & 2012 IECC \\
\hline Zone 1 & 17 & 14 & 12 \\
\hline Zone 2 & 20 & 16 & 14 \\
\hline Zone 3 & 19 & 16 & 14 \\
\hline Zone 4 & 19 & 16 & 14 \\
\hline Zone 5 & 19 & 16 & 14 \\
\hline Zone 6 & 19 & 16 & 14 \\
\hline Zone 7 & 19 & 16 & 14 \\
\hline Zone 8 & 22 & 18 & 16 \\
\hline National Average & 19 & 16 & 14 \\
\hline
\end{tabular}

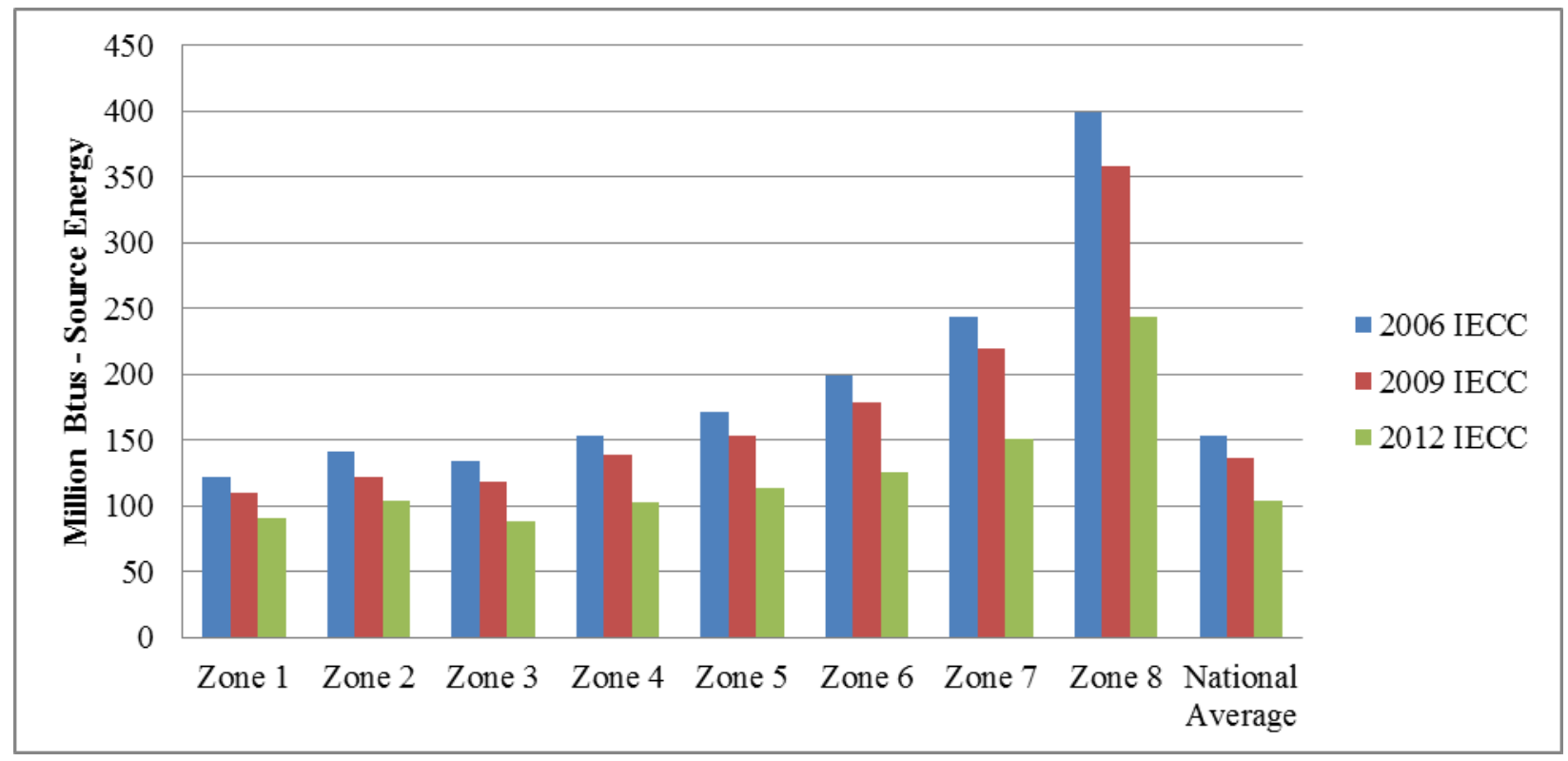

Figure 1. Annual Energy Use for a Dwelling Unit for all IECC Regulated End-Uses (Heating, Cooling, Water Heating, and Lighting) 


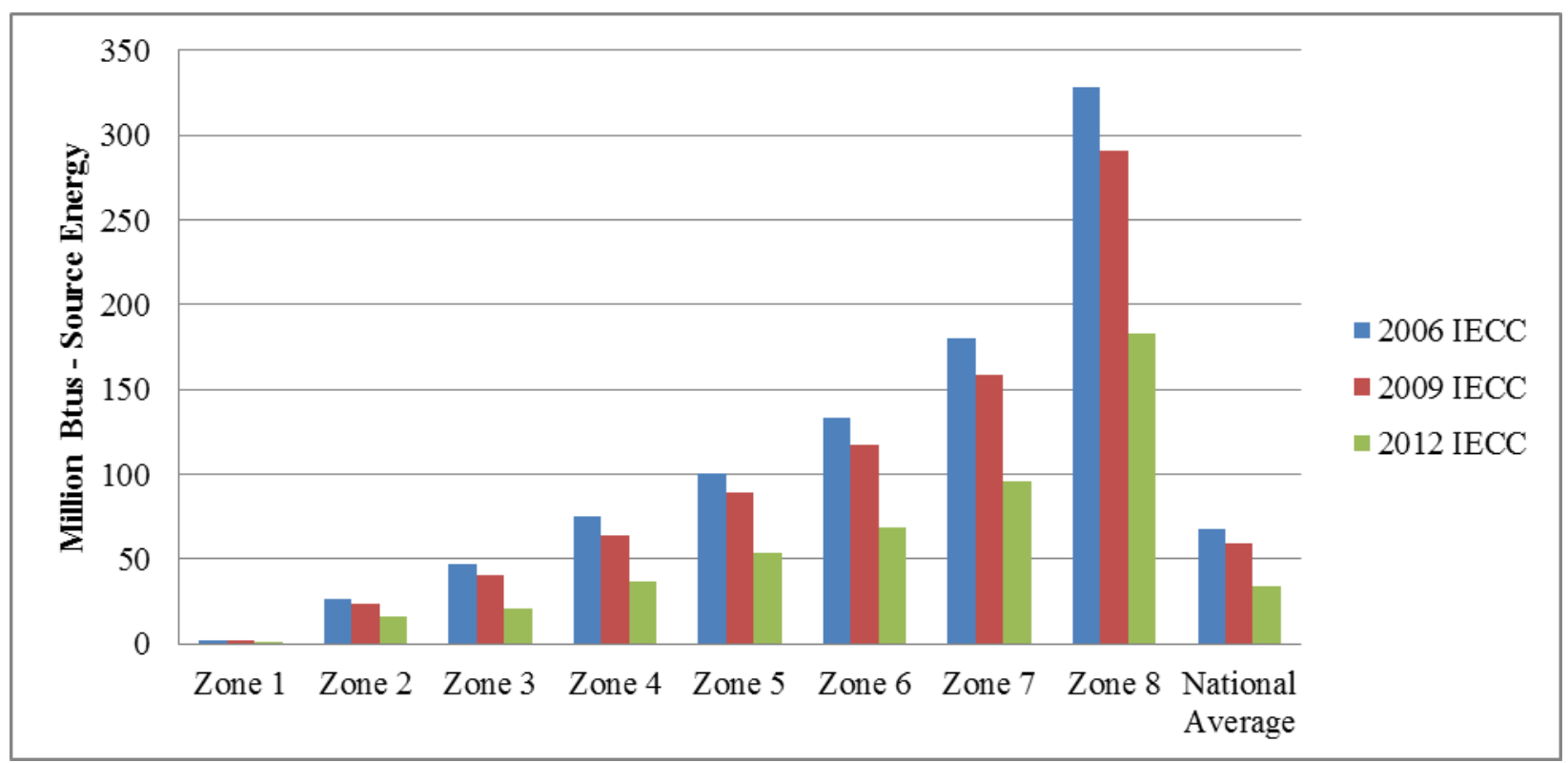

Figure 2. Annual Energy Use for a Dwelling Unit for Heating

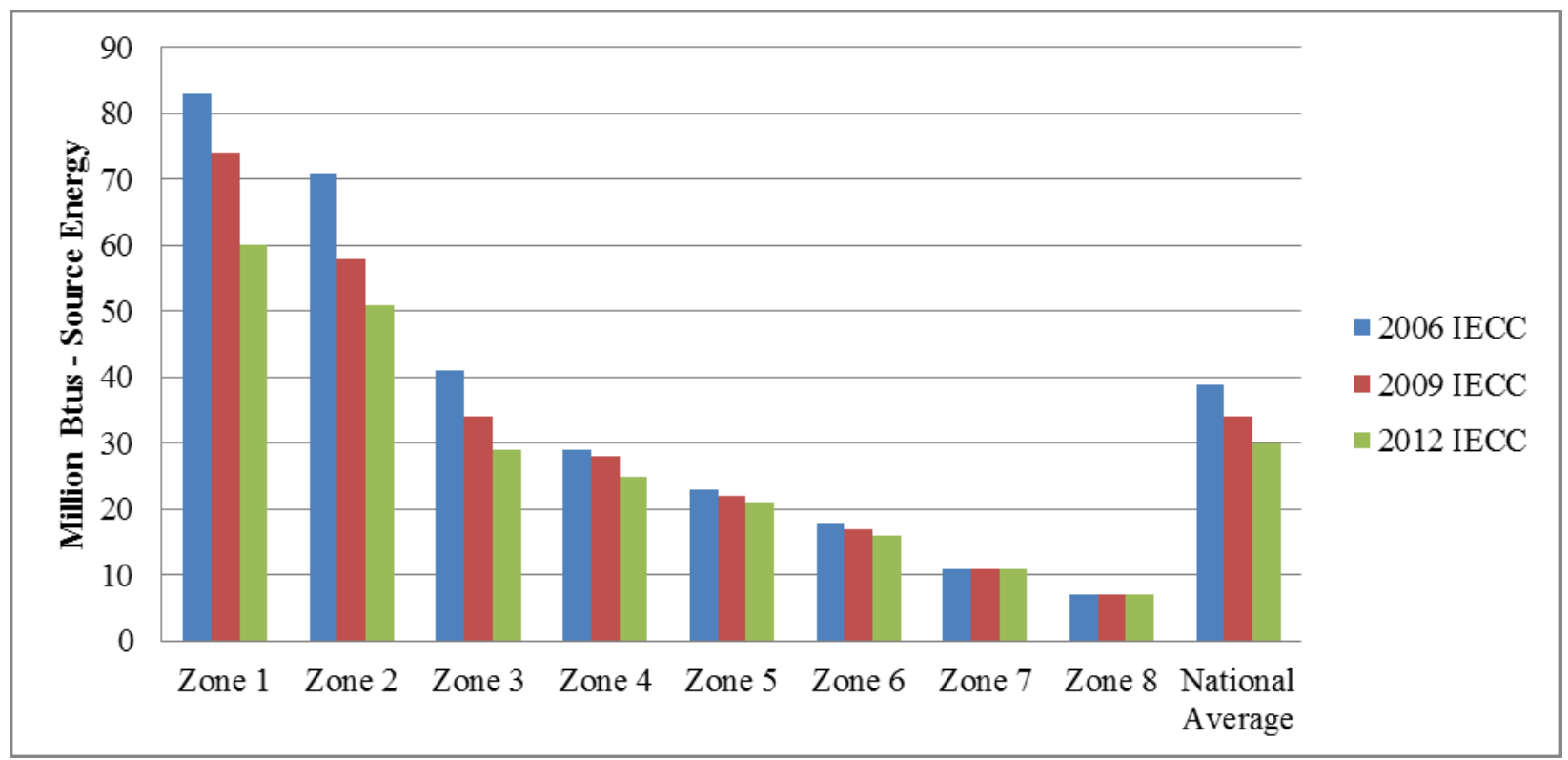

Figure 3. Annual Energy Use for a Dwelling Unit for Cooling 


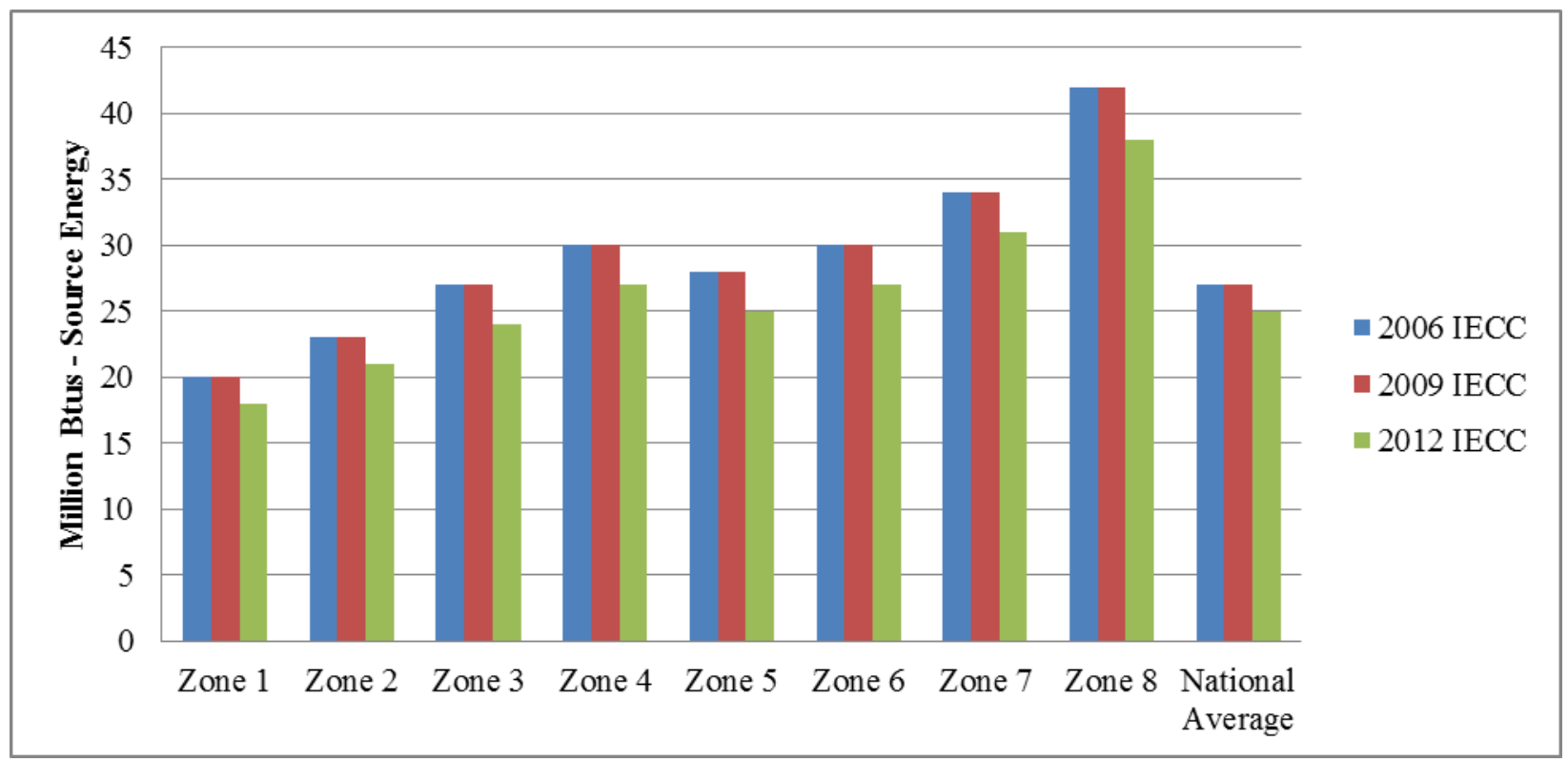

Figure 4. Annual Energy Use for a Dwelling Unit for Domestic Water Heating

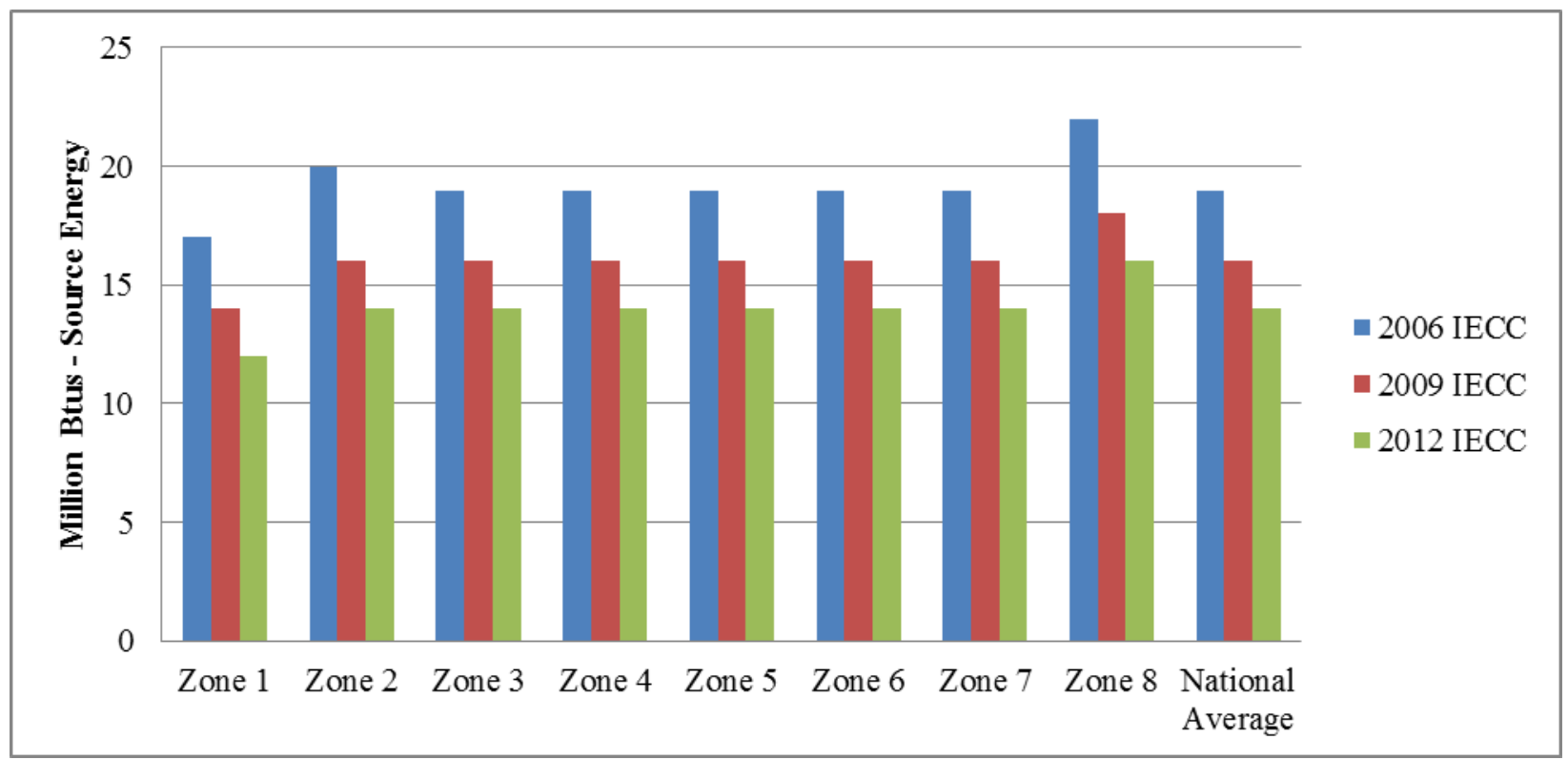

Figure 5. Annual Energy Use for a Dwelling Unit for Lighting

\subsection{Total Annual Energy Savings for all Residential Construction}

According to 2010 Census data, 537,157 building permits were issued nationwide for housing starts of low-rise residential dwelling units (single-family and multifamily less than three stories) in 2010. If all these were built to the 2009 IECC, a total of 8.59 trillion Btu would be saved annually as compared to the 2006 IECC. In comparison, for the same number of housing starts, the 2012 IECC would save 26.32 trillion Btu over the 2006 IECC. 



\subsection{References}

U.S. Department of Energy. Methodology for Evaluating Cost-Effectiveness of Residential Energy Code Changes. PNNL-21294. Washington D.C.

U.S. Department of Energy. 2012. National Energy and Cost Savings for New Single- and Multifamily Homes: A Comparison of the 2006, 2009, and 2012 Editions of the IECC. PNNL-21329. Washington D.C. 




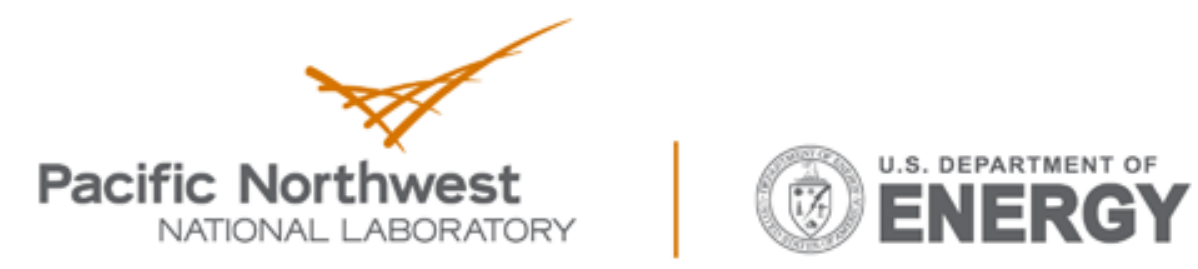

Proudly Operated by Battelle Since 1965

902 Battelle Boulevard

P.O. Box 999

Richland, WA 99352

1-888-375-PNNL (7665)

www.pnnl.gov 